\title{
BABYLONIAN TEXTS FROM THE FOLIOS OF SIDNEY SMITH, PART THREE: A COMMENTARY ON A RITUAL OF THE MONTH NISAN
}

\begin{abstract}
A. R. George
This study continues the series of articles that make available cuneiform texts in previously unpublished hand-copies left by the late Sidney Smith. ${ }^{1}$ The fragment presented here now rests in the British Museum's Sippar collections. ${ }^{2}$ As such it was listed by Erle Leichty in the first of his three monumental volumes of catalogue. ${ }^{3}$ It is accordingly a great pleasure to place the editio princeps of this piece in a volume honouring him.

The tablet BM 54312 (Fig. 1) is Neo- or Late Babylonian. It is part of a consignment that contained tablets from Babylon, as well as Sippar (82-522). To judge from the superscript, a standard invocation of Marduk and his consort expressing the hope that the tablet will be successfully completed, the provenance was indeed Babylon.

The tablet is certainly one of the most intriguing fragments found in Smith's folios of cuneiform copies, though only the obverse is preserved. According to format and style the text belongs to one of the classes of documents that are known in Assyriology as commentaries. ${ }^{4}$ There are essentially two types of commentary. The first type comprises fixed texts handed down as part of the scribal canon; good examples are the commentaries on Šmma $i z b u$ edited by Erle Leichty and other lexical commentaries that survive in multiple and duplicate manuscripts. ${ }^{5}$ The second type of commentary is that in which typically a phrase of text is cited and philological notes mixed with quotations and other comments are appended by way of elucidation. Where several tablets of this kind of commentary are extant for a given text of the
\end{abstract}

1 See earlier, "Babylonian Texts from the Folios of Sidney Smith, Part One," RA 82 (1988) 13962; "Babylonian Texts from the Folios of Sidney Smith. Part Two: Prognostic and Diagnostic Omens, Tablet I," RA 85 (1991) 137-67; "Royal Inscriptions from the Folios of Sidney Smith," in Studies Grayson 137-44. The remaining copies of Babylonian tablets in the folios are either incomplete or have been superseded by the efforts of other scholars, published and unpublished. Some Old and Neo-Assyrian documents remain to be published, however.

2 BM 54312 is published by the good grace of Sidney Smith's son, Professor H.F. Smith, and with the permission of the Trustees of the British Museum. The tablet has been collated and a few minor alterations and additions have been made to Smith's copy in consequence.

${ }^{3}$ E. Leichty, Catalogue of Babylonian Tablets in the British Museum 6. Tablets from Sippar 1 (London: British Museum, 1986) 138.

4 See generally J. Krecher, “Kommentare," RlA 6 188-91.

5 For the Šumma izbu commentaries see E. Leichty, The Omen Series Šmma Izbu (TCS 4; Locust Valley: Augustin, 1970) 211-31. [Editors' note: see also I.L. Finkel in the present volume.] 


\section{A.R. George}

scribal tradition, as for example with Sakikku I, they are not true duplicates but read like individual records of traditional interpretations and customary explanations that were evidently attached to the text under comment by generations of Babylonian scholars and teachers. ${ }^{6}$ The presence in some of them of scribal notations such as hepi "break" shows that they came to be copied for their own sake. These scholia were not originally part of the written scribal tradition itself; they are better understood as witnesses to how students engaged with that tradition during their education. What is set down on BM 54312, however, cannot yet be proved to be a learned exposition of any text of the written tradition, for no extant text tallies with what is written on it; it may be that it comprises a learned exposition of what was never written down. Oral lore, as well as written, was discussed by scholar-teachers with their apprentices.

The surviving text sets down comments chiefly on the apparel worn by an unidentified subject during the period of 5-11 Nisan (Nisannu), the month of the New Year. These seven days were the time of a great festival at Babylon, for this was the crucial period when Nabû arrived from Borsippa, his father Marduk hosted the divine assembly in his temple E-sagil, and the gods accompanied them in procession to the Akitu-temple outside the city. There the gods witnessed Marduk's symbolic defeat of Ti'āmat, the Sea, before saluting his triumphal re-entry into the city. ${ }^{7}$ Other cities held similar festivals at one time or other but the superscribed prayer typical of tablets from Babylon and the presence of Marduk in the text itself makes it likely that the context of this commentary is the Akitu-festival of this god at Babylon.

The question of the main participant's identity is important for a proper understanding of what is going on. In the first line a sequence of damaged signs, $\mathrm{x}-\mathrm{x}-\dot{u}$, can hardly be other than a human subject who is in attendance

6 See George, "Babylonian Texts from the Folios of Sidney Smith. Part Two: Prognostic and Diagnostic Omens" 139-40. The observation made there, that though the three commentaries on Sakikku I "sometimes agree word for word, more often than not they treat the same subject in slightly different ways," is borne out by a newly published fourth exemplar, von Weiher, $S p T U$ V 256. This is very close to Commentary A but not an exact duplicate.

7 The standard edition of the rituals of Nisan at Babylon, specifically of E-sagil, the temple of Marduk, is still F. Thureau-Dangin, Rituels accadiens (Paris: Léroux, 1921) 127-54: "Le rituel des fêtes du Nouvel An à Babylone." In the interval since then other sources of the ritual and texts related to it have been published, notably the texts edited or re-edited by B. Pongratz-Leisten, Ina Šulmi İrub. Die kulttopographische und ideologische Programmatik der akītu-Prozession in Babylonien und Assyrien im 1. Jahrtausend v.Chr. (BaF 16; Mainz: Philipp von Zabern, 1994) 228-46; W. G. Lambert, "Processions to the Akitu House," RA 91 (1997) 49-80; A. R. George, "Four Temple Rituals from Babylon," in Studies Lambert 259-99, esp. 260-70 ("1. Nisannu?"). Another very probable source is that published by F. Köcher, "Ein mittelassyrisches Ritualfragment zum Neujahrfest," ZA 50 (1952) 192-202; for this, previously held to describe a festival imported to Assyria, see George, "Four Temple Rituals" 262-3 n. 17. 


\section{Babylonian Texts from the Folios of Sidney Smith}

on a deity in some capacity for the seven days of the period in question. The reason for his participation is explained in a broken clause of commentary, "[because of the ... that] the great lord Marduk did to him." Clearly the traces exclude both the human beings known to have been attendant on Marduk at this time, the priest-cum-valet who looked after him in his cult-chamber (the šešgallu) and the king.

One possibility is that the damaged signs in line 1 should be read ${ }^{\top} k u$ - $l u^{\top}-u^{8}$ and taken as an unusual rendering of $k u l u$ ' $u$, an effeminate or feminized (probably castrato) cultic performer. The same spelling is also found at least once elsewhere, in a Late Babylonian letter. ${ }^{9}$ In a synonym list kulu'u explains kurgarrû and assinnu, as well as various other more obscure persons. ${ }^{10}$ The functions and proclivities of the kurgarru and the assinnu are well known. They were cultic performers and included in their ranks transvestites, homosexual prostitutes, catamites, castrati, hermaphrodites and the like. ${ }^{11}$ Accordingly they occupied a lowly but special position in Babylonian society. In another lexical list the word kulu'u occurs as an alternative reading of the logogram lú.ur.SAL "female man, hermaphrodite," otherwise commonly read as assinnu. ${ }^{12}$ The two words are also variants in literature, both describing Așušu-namir, whom Ea made in order to amuse Ereškigal. ${ }^{13}$ Unlike an ordinary being Asûšu-namir could enter and leave the Netherworld at will, probably because, being neither male nor female, he was set apart from the mass of humankind and not governed by the usual regulations. ${ }^{14}$ Proof that the kulu'u was of special gender comes from a Middle Babylonian diplomatic letter in which the addressee is accused of insulting an exiled Assyrian prince by calling him "a kulu'u, not a man."15

8 The traces do not permit a reading $k[a-l] u-u$, "cult-singer."

9 CT 22 183, 9: lúku-lu-úmeš, ed. E. Ebeling, Neubabylonische Briefe (ABAW 30; Munich: Verlag der Bayerischen Akademie der Wissenschaften, 1949) 99.

10 CT 185 K 4193 rev. 9-11 restored from LTBA 21 vi 45-9// 2 380-3: i-sin-nu-u, a-pi-lu-u, kur-gar-ru-u, a-ra-ru-u, šu-da-ra-ru-u=ku-lu-'; cf. CAD K 529.

11 They are the subject of a large bibliography; see most recently Stefan M. Maul, "kurgarrû und assinnu und ihr Stand in der babylonischen Gesellschaft," in Außenseiter und Randgruppen. Beiträge zu einer Sozialgeschichte des Alten Orients (ed. Volkert Haas; XENIA 32; Constance: Universitätsverlag Konstanz, 1992) 159-71; W. G. Lambert, "Prostitution," in Außenseiter und Randgruppen 127-61, esp. 147-52; George, "Four Temple Rituals" 270-1 n. 21. A study from a more anthropological perspective is that by Gwendolyn Leick, Sex and Eroticism in Mesopotamian Literature (London: Routledge, 1994) chapter 14, "Liminal Sexuality: Eunuchs, Homosexuals and the Common Prostitute."

12 B. Landsberger and O. R. Gurney, "igi-duh-a = tāmartu, Short Version," AfO 18 (1957-58) 84, 265-6: lú.[ur.SAL] = ku-lu-', lú.ur.SAL = as-sin-nu.

13 Ištar's Descent: KAR 1 rev. 6': aș-na-me-er ku-lu-'-[a] // CT 1546 rev. 12: maṣ̂u(è)-šu na-mir lúas-sin-nu, ed. Borger, BAL I 101 Nin. 92 // Ass. Rs. 7.

14 So already Lambert, "Prostitution" 151.

15 IV R2 34 no. 2 rev. 21: ku-lu-'-ú la zi-ka-ru šu-ú, ed. J. Llop and A. R. George, "Die babylonisch-assyrischen Beziehungen und die innere Lage Assyriens in der Zeit der Auseinandersetzung zwischen Ninurta-tukulti-Aššur und Mutakkil-Nusku nach neuen keilschriftlichen 


\section{A.R. George}

The insult becomes sharper when one considers that a kulu'u, if he was like an assinnu, took the female role in homosexual intercourse.

The presence of a kulu' $u$ in Marduk's entourage is not without parallel. There is a tablet that specifically collects the Akkadian chants to be recited by a lúur.SAL (assinnu or kulu'u) during the progress of Marduk's procession to the $A$ kitu-temple on 8 Nisan. ${ }^{16}$ It may be that this person is identical with the subject of our text. One of the chants tells us that among those who took part in the procession were assinnus and kurgarrûs of Ištar, Lady of Babylon. ${ }^{17}$

The commentary states that a member of the kulu'u personnel (if correctly read) was obliged to attend Marduk during the ritual of the Akitu-festival, evidently because of something Marduk did to him. The following phrases of commentary refer to something - surely, whatever Marduk did to the x$\mathrm{x}-\dot{u}$ - as a "curse" that "cannot be undone." I suspect that what Marduk did was to determine the peculiar status of this class of person (by decreeing their castration?). Curse by a deity as an aetiology of the degraded status of cultic performers in Babylonian society occurs in the Descent of Ištar, where the assinnu (or kulu'u) Așûšu-namir and his kind are cursed by Ereškigal for thwarting her plans; according to one source her curse is similarly irrevocable, a "destiny not to be forgotten for all time." 18 Given the rarity of the spelling $k u-l u$ - $u$, this reading in the present text remains questionable. However, it is a reading that fits not only the traces but also the ancient exegesis set down in the opening lines, at least as I understand it.

If the first few lines of the text are to be interpreted as commentary relating to the kulu'u's status, the rest of it is commentary on ritual actions. It seems these ritual actions are in some way part of the cultic rites conducted from the fifth to eleventh days, but specifically the procedures of cult of a deity $\mathrm{d} a-[\ldots]$. Clearly this cannot be Marduk. Since in line 5 a feminine possessive pronoun is at issue, I assume the deity is a goddess, and at Babylon a goddess $\mathrm{d} a-[\ldots]$ is likely to be Anunnitum, who had a sanctuary in the temple complex of Marduk and is well known in the religious life of the city. ${ }^{19}$ She recurs in lines 5 and 6 . Now Anunnîtum is a form of Ištar and it is with Ištar's cult especially that cultic performers like the kurgarrî and the assinnu were most often associated.

Quellen," AfO 48-9 (2001-02) 1-23. The prince in question was the unfortunate Ninurtatukulti-Aššr.

16 K 9876+19534 obv. 1: [an-nu-ú] šá lúur.SAL imannû(šid), ed. Pongratz-Leisten, Ina Šulmi Irub 228. Singing also accompanied Marduk's return to E-sagil, though on that occasion it was a senior professional cult-singer (kalamāhu) chanting in Sumerian: see Jerrold S. Cooper, "A Sumerian šu-íl-la with a prayer for Sin-šar-iškun," Iraq 32 (1970) 51-67.

17 K $9876+19534$ obv. 11

18 KAR 1 rev. 19': šim-ti la ma-še-e ana șa-a-ti, ed. Borger, BAL I 101 Ass. Rs. 20.

19 For Anunnitum and her cult at Babylon see the temple list Tintir IV 10, ed. A. R. George, Babylonian Topographical Texts (OLA 40; Leuven: Peeters, 1992) 58-9 and commentary on 310 . 


\section{Babylonian Texts from the Folios of Sidney Smith}

The kulu' $u$ (if that is what he is) who must attend Marduk during his festival is thus revealed as an hermaphrodite attached to the cult of Anunnitum. The first ritual action that he performs (lines 4-5) is to sprinkle holy water, probably on her (i.e., the goddess's statue), an action that recalls how in mythology the kurgarra and galatur - in Babylonian Namtar, but implicitly compelled by the assinnu/kulu'u Aș̂ušu-namir-sprinkle Inanna/Ištar's dead body with the water of life in order to enable her return from the Netherworld. The ancient commentary, however, is silent on this point, remarking only that the sprinkling signifies the purification of the world.

The remainder of the text is devoted to the exposition of a second ritual action, namely an elaborate ceremony of dressing. Ritual attire was important in the Babylonian cult, not only for deities but also for their human attendants, as we know from a Late Babylonian tablet from Uruk that prescribes the garments and headgear to be worn by various participants in the cult, including the king. ${ }^{20}$ The subject in BM 54312 is no doubt the mysterious personage of line $1, k u l u^{\prime} u$ or no, and the assumption adopted here is that this ceremony is to make him suitably splendid for his role in Marduk's Akitu-festival. His basic dress is given by the text as "apparel of Anunnitum." As well as serving to remind us that the activities of the subject are bound up with the "rites of Anunnitum" (as restored here), this is further evidence of his identity as a cultic performer. Other references exist to such personnel wearing the accoutrements of a goddess: a ritual from Uruk describes a kurgarrî and an assinnu as wearing the till $\hat{u}$-sash of the goddess Narudu while accompanying Ištar to the Akitu-temple, ${ }^{21}$ and a commentary on a tablet of diagnostic omens quotes in the context of cultic ecstatics a lexical entry lú.giškéš.da nin nun.gal.e.ne "one (sporting) the knot of the mistress of the Igigi" = ri-kis $\mathrm{d} n a-r u-d u$ "(one sporting) the knot of Narudu."22 It is suspected that some of the cultic personnel of Ištar wore female attire; some certainly carried spindles as a mark of their vocation or gender. ${ }^{23}$ The present attestation of the subject dressing in the garments of Anunnitum appears to be a further example of transvestism.

After donning the apparel of Anunnitum the subject of the ritual must adorn himself with the following items:

20 A. Falkenstein, “Zwei Rituale aus seleukidischer Zeit," UVB 15 (1959) 40-4 no. 2.

21 RAcc. 115, 7, ed. S. Lackenbacher, "Un nouveau fragment de la 'fête d'Ištar'," $R A 71$ (1977) 46, 25': śá til-le-e d na-ru-du rak-su. The tillû of this goddess is a distinctive attribute, used elsewhere to identify an apotropaic figurine as her representative: see $B B R$ no. 45 iii 1 , ed. F. A. M. Wiggermann, Mesopotamian Protective Spirits: The Ritual Texts (CM 1; Groningen: Styx, 1992) 12, 138-9.

22 Commentary a on Sakikku I 30, ed. George, "Babylonian Texts from the Folios of Sidney Smith, Part Two" 150-1 // von Weiher, SpTU V 256 rev. 6'.

23 See the lexical text Lú = $\check{a} a$ I 217 (ed. MSL 12 103), where lú.gišbal.šu.du $7=n a-a ́ s ̌ ~ p i-l a q-q i$, "spindle bearer," follows entries for kurgarrû and assinnu. 


\section{A.R. George}

(a) seven waistbands

(b) fourteen writing styli of reed, seven strapped at his right side, seven at his left

(c) two more styli, two at the front and two at the back

(d) two upper overgarments and two lower overgarments

(e) belts, evidently two in number

(f) an unidentified item (text damaged) worn behind the waist

(g) fourteen twists of coloured wool, seven on the right and seven on the left

(h) another unidentified item, made of linen

(i) headgear?

The interest of the text in listing this elaborate costume is again expository, for each item is subject to phrases of commentary. The sole aim of the commentary on this passage is equation of the individual items of clothing and regalia with members of the pantheon. In the Seleucid tablet from Uruk the garments of the temple personnel (érib biti) are adorned with representations of seven minor guardian deities. ${ }^{24}$ The technique used in the present text, however, is to maintain that the items worn actually bear the names of gods. This makes for a specific identification between object and god. The seven styli worn on the right (b) are identified by name as the great triad of Anu, Enlil, and Ea, the three celestial deities of sun, moon, and Venus, and the Mother Goddess. Those on the left (also b) bear the names of a group of seven Babylonian gods known in antiquity as the "seven Ninurtas": Uraš of Dilbat, Ninurta of Nippur, Zababa of Kiš, Nabû of Borsippa, Nergal of Cutha, Madānu of Babylon, and Pabilsag of Isin. The styli of front and rear (c) are called after the Mother Goddess and the goddess Gula in her title of Nintinugga, Lady who Quickens the Dead. The seven waistbands (a) are named Ištar and Ea; the presence of two deities only, and out of sequence, may mean that the writer of the commentary misunderstood something. ${ }^{25}$

The twin sets of two overgarments (d) are called after the chthonic twins Lugalirra and Meslamtaea and two apotropaic monsters, Lion-Demon and Dragon. The belts (e) are named as the vizier Papsukkal and his master, Anu. The unidentified item worn behind the waist (f) is the Mother Goddess. The seven twists of coloured wool on the right $(\mathrm{g})$ are identified as the Pleiades, the seven on the left (also g) are a heptad of waterways, not all of them identifiable. We are reminded that in ancient Mesopotamia the pantheon contained not just the anthropomorphic figures of mythology; stars and rivers were held divine also. As the text fails us it seems that a linen item (h) and headgear are at issue (i), and the Moon God is mentioned, appropriately in the context, for he is often addressed as bèl age "lord of the crown."

${ }^{24}$ Falkenstein, "Zwei Rituale" 40 rev. 13'-15'.

25 See below, the note on the text. 


\section{Babylonian Texts from the Folios of Sidney Smith}

The principle according to which inanimate or mundane objects can be equated with prominent deities of the pantheon was well established in Babylonian scholarship. The ancient texts that articulate such equations most clearly are those studied and elucidated by Alasdair Livingstone, particularly the lists that explain as deities ritual equipment and materials used in temple and exorcistic rituals. ${ }^{26}$ In these lists simple equations are made so that everyday objects in use in a ritual signify deities. Sometimes there is a clear rationale, as in the classic example when gypsum and bitumen are identified respectively as Ninurta and the Asakku demon, famous opponents in mythology. ${ }^{27}$ In the mythological narrative Lugale Ninurta is champion of the established and familiar order, while the Asakku represents the ungovernable and foreign chaos that threatens that order. In the equations of the lists, the white substance is naturally the good Ninurta, the black material is the evil Asakku. In practice these two substances, washes of gypsum and bitumen, are daubed by the medicine man (āsipu, "exorcist") on the doorway of the house where his patient lies sick. According to the symbolism of the list they signify the presence of Ninurta and the Asakku, in the expectation that just as Ninurta won in the primeval combat of mythology, so he will again when battle is rejoined in the doorway. With the Asakku vanquished, the demonic influences that have caused the patient's illness will be banished.

As Livingstone points out, the rationale behind the equations of his texts cannot always be identified as easily, and many of the identifications remain a matter of mystery. What seems certain, nevertheless, is that the interpretations of ritual equipment and other objects may be informed by mythology, so that individual items evoke individual episodes or mythologems that are appropriate, but the ensemble does not itself tell a myth. This is sure proof that the equation between object and deity was a secondary development. Just as learned pseudo-etymological texts manipulate the spelling of proper nouns - typically the names of gods, cities, and temples - in order to bring esoteric meanings to light that reveal hidden and mystical truths about the nature of the names' bearers, ${ }^{28}$ so the scholars who developed the technique of explaining ritual objects in terms of gods and goddesses sought to invest in those objects the numinous powers of the supernatural world and to bring those powers into play in the ritual.

26 A. Livingstone, Mystical and Mythological Explanatory Works of Assyrian and Babylonian Scholars (Oxford: Clarendon Press, 1986) esp. chapter 5; see in addition W. G. Lambert, "The Qualifications of Babylonian Diviners," in Studies Borger 151.

27 On this see already W. G. Lambert, "Myth and Ritual as Conceived by the Babylonians," JSS 13 (1968) 104-12, esp. 110.

${ }^{28}$ For examples of these texts see J. Bottéro, "Les noms de Marduk, l'écriture et la 'logique' en Mésopotamie ancienne," in Studies Finkelstein 5-28; Livingstone, Mystical Works 54-63; W. G. Lambert, "A Late Babylonian Copy of an Expository Text," JNES 48 (1989) 215-21; George, Topographical Texts nos. 2-5, $18 \S 6,19,20 \S 4,22-3$, and 31. 


\section{A.R. George}

Such was also the intent of whatever sources, written or memorized, informed the commentator of the present text. The equations are very evidently symbolic. The wearer of the garments and regalia is no longer himself but, by virtue of the identification of his apparel with deities great and small, he is the entire pantheon of heaven and earth, going to march alongside Marduk, the king of the universe, in his symbolic battle with the watery forces of chaos. This explains why Marduk does not appear among the gods chosen by the commentator. All the other great figures of the Babylonian pantheon are there, except Adad. I cannot find a reason for Adad's absence, but the context of the ritual itself explains the omission of Marduk. The suggestion is that a kulu' $u$ from the personnel of Anunnitum of Babylon is to accompany Marduk for the seven days of Nisan during which Marduk's statue is prepared for the journey to the Akitu-temple and makes the procession there and back. The apparel that he wears very appropriately represents and symbolizes the assembly of the gods subservient to Marduk; it does not include in that number the king of the gods himself, for Marduk travels under his own identity.

BM $54312(82-5-22,464)$

Superscript

[ina $a$-mat $\mathrm{d} b \bar{e}] l(\mathrm{en}) u$ d bèlti(gašan)-iá liš-lim

Text

$1[\mathrm{x} \mathrm{x} \mathrm{x}] \mathrm{x}\left[\mathrm{x}\right.$ it ${ }^{i} n i s a n n u\left(\right.$ bar) $i s ̌ t u(t a)$ ud 5.kam adi(en) ud 11.kam $7 u_{4}-m u$ x x-ú ina pān(igi) ${ }^{\mathbf{d}_{\mathrm{d}}}[\ldots]$

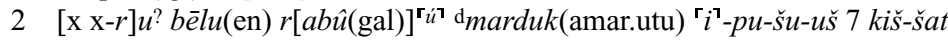
šamê(an) $)^{e} u$ erseti $(\mathrm{ki})^{\text {tim }}$ áš-šú $\mathrm{x}[\ldots]$

3 [x x ]x-ri á[r-ra]t-su la ip-pa-ša-ri áš-šú ištu(ta) ud 5.kam adi(en) ud 11.kam par-șu šá $\mathrm{d}{ }^{\mathrm{r}} a^{\top}-[$ nu-ni-tum? ... ]

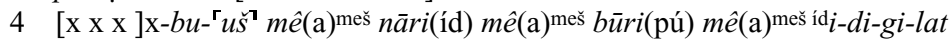
$m \hat{e}(\mathrm{a})^{\mathrm{meš}}$ id $p u$-rat-tú [0?]

5 [i-na sa-r]a-qí-šá mātātu(kur)meš ú-tal-lal 3.ta túgnahlapāt(gú.è) kitê(gada) su-bat $\mathrm{d} a$-nu-ni-tum ih-ha-l[ip]

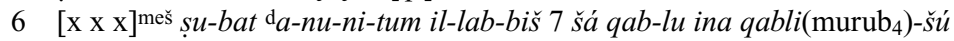
$i-r a k-k[a s]$

$7 \quad[7$ gi qa-a]n-țp-pi ana imni(15) i-sa-an-ni-ib 7 gi qa-an-țp-pi ana šumēli(150) KIMIN 2 giqa-an-țup-pi

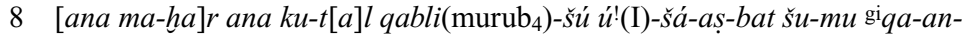
tup-pimeš śá im-nu $\mathrm{d} a-n u m$

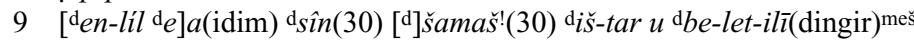
šùm-šú-nu šu-mu KIMIN

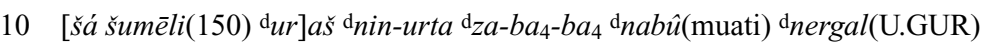
dmadānu(di.kud) $u$ dpa-bil-sag šùm-šú-nu 


\section{Babylonian Texts from the Folios of Sidney Smith}

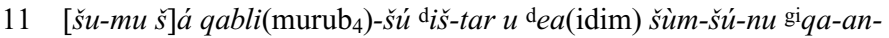
tuppī(dub)meš ma-har u ku-tal-l[a]

12 [dbe-let]-ili(dingir) $u$ dnin-tin-ug ${ }_{5}$-ga šùm-šú-nu 2 șu-bat e-lu-tú 2 šap-lu-tú šá $i s ̌ t u(\mathrm{ta})$ muhhi(ugu) kišādi(gú)-šú

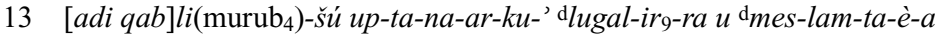
š̀̀m-šú $-n u$

$14\left[{ }^{\mathrm{d}} u_{4}-g a l\right]-l u u$ d mušh̆uššu(muš.husš) šùm-šú-nu túgnēbehu(íb.lá) šá ina

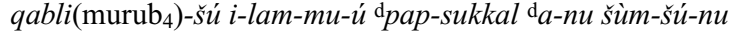

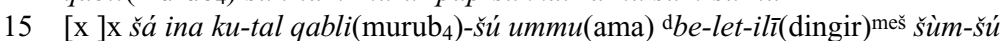
síkpeșâtu(babbar) síksāmātu( sa $_{5}$ ) síkuqnâtu(za.gìn.na) 7.ta.àm šá im-[n]u

$16\left[u\right.$ šumēl] $i(150)$ šá iš-tu qabli(murub $\left.{ }_{4}\right)$-šú uz-zu-nu šá im-nu mul zappu(mul) šùm-šú šá šumēli(150) 7 nārātu(íd) ${ }^{\mathrm{m}}\left[{ }^{[}{ }^{-s ̌]}\right]$

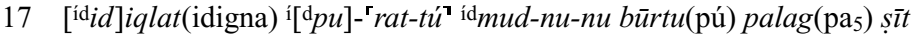
šamši (dutu.è.a) palag $\left(\mathrm{pa}_{5}\right)$ ereb šamši(dutu.šú.a) šùm-šúu- $n[u]$

$18[\mathrm{x}$ x x] x[ x x x] GAN šá kitê(gada) šu-ú și šam-ši den-líl-ú-tú ka-as-ka-s[i]

$19[\ldots .$.$] -ig-ri \mathrm{d}_{\sin }(30)$ ku-lu-lu qaqqadi(sag.du)-šú aššu(mu) ${ }^{n_{4} k u n u k k u}$ (kišib) ${ }^{n a} a \check{s}-p u ́-u$ aban(na 4 šarru(lugal)-[ti ... (remainder lost)]

Translation

By the command of Bēl and Bēltīya let it be a success!

[...] from the fifth to the eleventh day of Nisannu, for seven days the ... [stands] before the god [DN, because of the ...] the great lord Marduk did to him. Seven $=$ all heaven and underworld, because ... [...] ... His [curse] cannot be undone, because from the fifth to the eleventh day the rites of [Anunnitum ...] ... him. River water, well water, Tigris water, Euphrates water $\left[(\ldots)^{5}\right.$ as he] sprinkles on her $^{29}$ all the lands are purified. He wraps himself in three linen cloaks, the attire of Anunnîtum. He puts on $[x \ldots]$..., the attire of Anunnîtum. He ties seven waistbands around his waist. He fastens [seven reed] styli to the right, ditto seven reed styli to the left. Two reed styli he positions [to the front] and to the rear of his waist. The names of the reed styli on the right: they are called Anu, [Enlil], Ea, Sîn, Šamaš(!), Ištar, and Bēlet-ilī. The names of ditto ${ }^{10}$ [on the left]: they are called Uraš, Ninurta, Zababa, Nabû, Nergal, Madānu, and Pabilsag. [The names of] his waistbands: they are called Ištar and Ea. The reed styli front and rear: they are called [Bēlet]-ili and Nintinugga. The two upper garments and two lower ones which they drape across from the top of his shoulder [to] his waist: (the two) are called Lugalirra and Meslamtaea; (the others) are called [Lion]-Demon and Dragon. The belts which they put around his waist: they are called Papsukkal (and) Anu. ${ }^{15}$ [The ...] ... which is behind his waist: it is called Mother Bēlet-ilī. The (twists of) white, red and blue wool, seven each on right [and left], which ... from his waist: those of the right are called the Pleiades, those of the left are called the Seven Rivers: Tigris, Euphrates, Mudnunu(?), Well-spring(?), Eastern Canal, Western Canal. [...] ... [...] it is a ... of linen, east $=$ Enlil-ship, breastbone, $[\ldots] \ldots$ Sin, the kerchief of his head, because a seal of jasper, the stone of kingship [... (remainder lost)]

29 Or, "as she sprinkles," with reference to a feminine subject. 


\section{A.R. George}

\section{Notes}

2. The mystic figure seven, which refers back to the number of days given in the previous line, is also equated with $k i s ̌-s ̌ a-t u$ in a group vocabulary (F. Thureau-Dangin, "Un vocabulaire de Kouyoundjik," RA 16 [1919] 166 ii 24 // CT 1829 ii 19). Compare also lugal.ú-mu-na7 = šar-ru kiš-šá-ti in Lú $=\check{s} a$ I 52 (ed. MSL 12 94), and 7.àm dingir 7.àm.meš : se-bet ilī(dingir)meš $k i \check{s}$-šá-ti in Udug-hul V (CT 1613 iii 18).

4. GI is written for $\mathrm{IG}(i q)$, as elsewhere in Neo- and Late Babylonian writing. The use of CV signs for VC is well documented for Neo-Assyrian orthography (see K. Deller, "Studien zur neuassyrischen Orthographie," Or NS 31 [1962] 188-90), but not yet for Babylonian of the same period.

5. The antecedent of the pronominal suffix on sarāqīša is presumed to be the goddess as object; less likely it is the ritual's protagonist as subject. Though in ancient Mesopotamia hermaphrodites had feminine gender as well as masculine, elsewhere in this text the person who is the ritual's only human participant consistently attracts a masculine pronoun. The spelling $\dot{u}$-tal-lal stands for 3rd fem. pl. ùtallalā, CVC for CVCV.

6. The figure seven is probably a mistake for two, since it appears from line 11 , as restored here, that the waistbands are equated with only two deities.

7. The styli are apparently attached to the waistband. A similar arrangement is found in relation to divine apparel in the fragment Rm 908, 4-5: ...] x-'

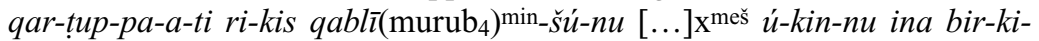

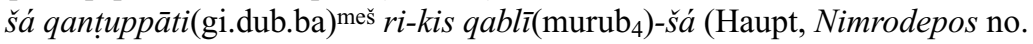
50, ed. A. Livingstone, Court Poetry and Literary Miscellanea [SAA 3; Helsinki: Helsinki University Press, 1989] no. 49). These attestations of styli tied to clothing help explain the túglu-bar qa-an-tup-pu worn by the king when taking the hands of the gods of Uruk (Falkenstein, "Zwei Rituale" 40 rev. 9'). Falkenstein thought this was a garment with a stylus pattern ("ein Kleid mit einem Schreibrohr-Muster"); a robe adorned with clutches of styli now seems more probable.

9. The second $\mathrm{d} 30$ is dittography, an obvious error for $\mathrm{d} 20$.

10. The seven gods of the left were known in antiquity as the "seven Ninurtas," under which rubric they are listed in the Archive of Mystic Heptads (KAR 142 i 22-5, ed. Pongratz-Leisten, Ina Šulmi İub 221): duraš dnin-urta d $z a-b a_{4}$ -

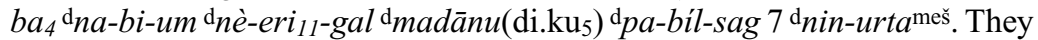
also appear as a group in a expository text concerning the rituals for repairing 
divine statues in the temple workshop (newly re-edited by C.B.F. Walker and M. Dick, The Induction of the Cult Image in Ancient Mesopotamia: The Mesopotamian Mīs Pî Ritual [SAALT 1; Helsinki: Neo-Assyrian Text Corpus Project, 2001] 240, 30'-1'): d uraš dnin-urta $\mathrm{d} z a-b a_{4}-b a_{4} \mathrm{~d}_{n a b \hat{u}(m u a t i)}$ dnergal(U.GUR) d madānu(di.ku $\left.{ }_{5}\right) u$ dpa-bill-sag.

\section{The spelling up-ta-na-ar-ku-' stands for II/3 present uptanarrakū.}

14. If the two deities equated with the second set of garments are to form a true pair, as did the first set, then an apotropaic monster comparable to the mušhušš is needed at the beginning of the line. Accordingly a possible restoration might be $\left[\mathrm{ku}_{6} . l u\right.$. $\left.\mathrm{u}_{18}\right] .1 \mathrm{lu}$, but the ugallu is preferred here because it appears more often adjacent to the mušhhušš in lists of apotropaic monsters found in litanies of absolution and other texts, and the pairing may thus have been traditional (for these lists, given in tabulated form, see George, "Babylonian texts from the folios of Sidney Smith, part one" 151; PongratzLeisten, Ina Šulmi İub 23).

15. The adj. sāmu in the fem. pl. is given as the rendering for sík.sa ${ }_{5}$ by analogy with not only sík.babbar = peșâtu and sík.za.gìn = uqnâtu but also other colours and varieties of wool (see Hh XIX 23-92, ed. MSL 10 128-30).

16. The verb $u z-z u-n u$ is obscure to me; emend to $u z-z u$ - hu $u$, which are girt"?

17. It does not seem possible to extract the expected seven rivers from this line: id $m u d-n u-n u$ is not a known watercourse, to my knowledge, and bürtu (or büru) is hardly a river. Corruption is suspected and the reading of the middle of the line is provisional. The "Eastern Canal" calls to mind the Lîbil-hengalla canal at Babylon, which was often given this epithet (Tintir V 61, ed. George, Topographical Texts 66 with commentary on pp. 356-8). Another list of seven rivers occurs in a lipšur-litany, K 2096 (Craig, ABRT I 57 obv. 24-5): ídidigna ídburanun idme.kal.kal iddur.ùl i $\left[{ }^{\mathrm{d}} \mathrm{x}(\mathrm{x}){ }^{\mathrm{i}}\right.$ ídGI.NUMUN id $a$-ra-ah-tum na-ram-ti dmarduk(amar.utu).

18. The explanation of și ̌̌amši "sunrise, east" as ellilūtu reports a wellentrenched belief that the east was Enlil's direction. This notion is found in scholarly lists that identify the four winds with the chief deities of the pantheon (see Livingstone, Mystical Works 75-6). The east wind is šadh, and the association with Enlil no doubt rests on the use of $\check{s} a d \hat{u}$, "mountain," and its synonyms as epithets of this god.

19. A seal of jasper "stone of kingship," with suitable inscription, is known to have been strung around the neck of Sîn's statue in E-ḩulhul by Aššurbanipal, 


\section{A.R. George}

as Nabonidus reports (L. Messerschmidt, "Die Inschrift der Stele Nabuna'ids, des Königs von Babylon,” MVAG 1896, 1: 81, col. x 32 ff.): na 4 kunukki(kišib) ${ }^{n} a_{4} a \check{s}-p u ́-u$ šu-qu-ru aban(na $\left.{ }_{4}\right) \check{s} a r r u($ lugal)-tú; recently re-edited by $\mathrm{H}$. Schaudig, Die Inschriften Nabonids von Babylon und Kyros' des Großen samt den in ihrem Umfeld entstandenen Tendenzschriften: Textausgabe und Grammatik (AOAT 256; Münster: Ugarit-Verlag, 2001) 5223.3 col. x 32'-4' with n. 797. 


$$
8
$$

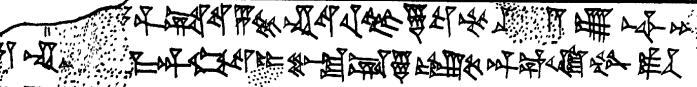

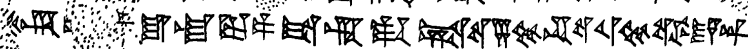

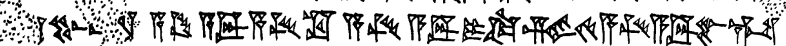

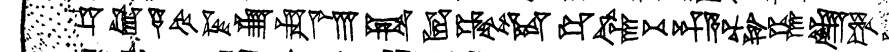

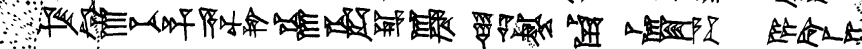

广

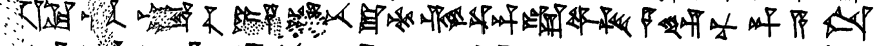

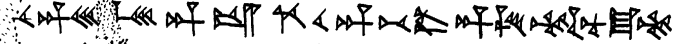

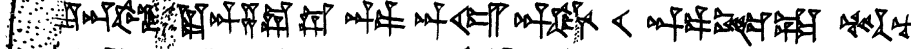

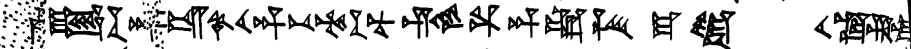

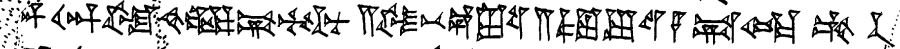

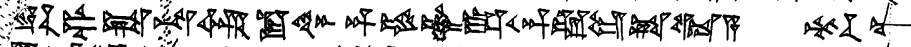

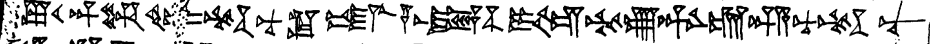

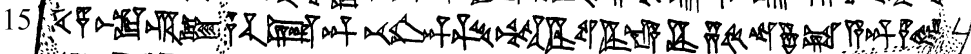

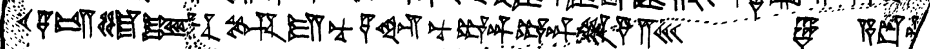

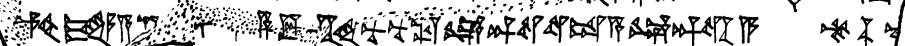

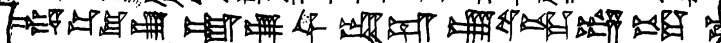

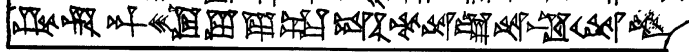

Fig. 1. BM 54312 (82-5-22, 464). Copy by Sidney Smith, adjusted by the author 